\title{
UPAYA PENINGKATAN PRESTASI PADA PELAJARAN IPS DENGAN MENGGUNAKAN MODEL PEMBELAJARAN GROUP INVESTIGATION PADA SISWA KELAS IV
}

\author{
Ilham \\ Ilhamakbar689@gmail.com \\ SDN Siwalanrejo Kecamatan Sukodadi
}

\begin{abstract}
Abstrak
Pembelajaran pada era sekarang diharapkan dapat menghadirkan suasana baru bagi siswa-siswinya, oleh karena itu pembelajaran yang diberikan pada saat PBM berlangsung harus bisa memberikan suasana yang bisa membuat siswa-siswinya lebih termotivasi untuk belajar.

Pengguinaan model pembelajaran Group Investigation ( melalui metode diskusi dan kerja kelompok ) ternyata memberikan pilihan terbaik, karena siswa lebih termotivasi,antusia dan bersemangat dalam mengikuti pembelajaran yang dilakukan oleh guru. Suasana pembelajaran lebih hidup karena siswa dapat berdiskusi memecahkan permsalahan yang diberikan oleh guru dan mengerjakan tugas dari guru secara kelompok.

Pada penelitian ini subyeknya adalah siswa kelas IV SDN Siwalarejo Kecamatan Sukodadi Kabupaten Lamongan sebanyak 17 siswa. Dengan menggunakan Tehnik Penelitian Tindakan Kelas sebanyak 2 siklus. Dari siklus I ke siklus II ternyata ada pengaruh yang signifikan. Pada Siklus I ketercapaian prosentase ketuntasan adalah $47 \%$ sedangkan pada siklus II mencapai ketuntasan maksimal yaitu 100\%. Sedangkan nilai rata-rata ulangan pada siklus I adalah 61 dan pada siklus II naik menjadi 80.

Dari penelitian ini dapat disimpulkan bahwa ada pengaruh positif antara penggunaan metode diskusi dan kerja kelompok dalam meningkatkan prestasi siswa.
\end{abstract}

\section{Kata Kunci : Pelajaran IPS, Group Investigation}

\section{PENDAHULUAN}

Sebagai lembaga yang secara langsung mendidik anak - anak untuk dipersiapkan ke jenjang selanjutnya, keterlibatan masyarakat serta pemerintah sangat dituntut agar apa yang diharapkan dapat terwujud. Keterlibatan ini menjadi suatu yang tidak bisa ditawar - tawar lagi dengan adanya peningkatan perkembangan Ilmu Pengetahuan dan Tehnologi yang semakin pesat di semua sektor kehidupan manusia. Pada mata pelajaran IPS di Sekolah Dasar terkesan banyak siswa yang merasa kesulitan dalam belajranya. Hal ini disebabkan karena mata pelajaran IPS memiliki scope ( ruang lingkup ) yang sangat luas dan kompleks. Membaca, menghafal konsep ,dirasa sangat membani bagi hamper kebanyakan siswa. Apalagi dalam struktur kurikulum, mata pelajaran IPS memiliki jumlah jamyang sedikit,Ber dsarkan hal tersebut,maka guru pada saat mengajar pelajaran IPS harus sangat krestif agar siswa tidak bosan,jenuh dan merasa drop. Berbagai macam cara dan upaya dilakukan oleh guru agar siswa dapat termotivasi untuk bersemangat dalam mempelajari mata pelajaran IPS. Dalam kehidupan sehari - hari, IPS bisa membantu sisw untuk bisa lebih mengenal social,budaya,ekonomi dan geografis. Berdasarkan uraian diatas,maka pada penelitian ini, guru mencoba untuk memprktekkan penggunaan model pembelajaran Group Investigation melalui metode diskusi dan kerja kelpmpok. Secara umum permasalahan penelitian ini dirumuskan "Bagaimana penggunaan model pembelajaran Group Investigation ( melalui metode diskusi dan kerja kelompok ) di kelas IV dalam pembelajaran IPS di SDN Siwalanrejo Kecamatan Sukodadi Kabupaten Lamongan Tahun Pelajaran 2017/2018?’ Petanyaan umum tersebut diuraikan ke dalam beberapa pertanyaan khusus yang merupakan permasalahan yang ingin diungkapkan melalui penelitian ini, yaitu: (1) Apakah penggunaan model pembelajaran group investigation melalui metode diskusi dan kerja kelompok dalam 
pembelajaran Pendidikan IPS dapat meningkatkan kualitas pembelajaran yang diselenggarakan guru ? (2) Apakah dengan menggunakan model pembelajaran group investigation melalui metode diskusi dan kerja kelompok dapat meningkatkan perolehan hasil belajar siswa kelas IV di SDN Siwalanrejo Kecamatan Sukodadi Kabupaten Lamongan tahun Pelajaran 2017/2018 ? (3) Bagaimana persepsi siswa kelas IV SDN Siwalanrejo Kecamatan Sukodadi Kabupaten Lamongan Tahun Pelajaran 2017/2018 terhadap pelaksanaan pembelajaran dengan menggunakanmodel pembelajaran group investigation melalui metode diskusi dan kerja kelompok ? (4) Faktorfaktor apa saja yang menjadi kendala dalam melaksanakan proses pembelajaran IPS di kelas IV SDN Siwalanrejo Kecamatan Sukodadi Kabupaten Lamongan Tahun Pelajaran 2017/2018 dengan menggunakan model pembelajaran group investigation melalui metode diskusi dan kerja kelompok ?

Sesuai dengan masalah penelitian tersebut, maka tujuan yang ingin dicapai dari hasil penelitian antara lain : (1) Untuk mengetahui kualitas pembelajaran Pendidikan IPS dengan menggunakan model pembelajaran group investigation melalui metode diskusi dan kerja kelompok. (2) Untuk mengetahui pengaruh penerapan Model Pembelajaran group investigation dengan menggunakan metode diskusi dan kerja kelompok. (3) Untuk mengetahui persepsi siswa terhadap pelaksanaan pembelajaran dengan menggunakan model pembelajaran group investigation melalui metode diskusi dan kerja kelompok. (4) Untuk mengidentifikasi faktor-faktor yang menjadi kendala dalam melaksanakan Model Pembelajaran group investigation dengan menggunakan metode diskusi dan kerja kelompok.

Penelitian ini diharapkan dapat bermanfaat bagi peneliti dan pihak-pihak lain sebagai berikut : Manfaat yang diperoleh guru bidang studi Pendidikan IPS, yaitu : (a) Memberikan perbaikan cara mengajar guru, bagaimana mengaktifkan siswa dengan menggunakan metode diskusi dan kerja kelompok. Menemukan pola pembelajaran Pendidikan IPS di sekolah dasar yang efektif melalui penggunaan metode diskusi dan kerja kelompok.

Manfaat yang diharapkan dan diperoleh siswa dan penelitian ini, yaitu : (a) Mengembangkan pola pikir siswa ke arah pemikiran proses. (b) Menumbuhkan minat dan motivasi belajar siswa untuk lebih giat dan bersungguh-sungguh dalam mengembangkan aktivitas dan kreativitas berpikir secara ilmiah.

Bagi Sekolah

Membantu sekolah untuk berkembang, karena dengan adanya PTK ( Penellitian Tindakan Kelas ) akan meningkatkan kemampuan siswa dan guru yang berdampak pada peningkatan kemajuan sekolah.

Banyak pihak termasuk dari kalangan pendidik yang menggunakan pengertian rancu tentang ilmu pengetahuan sosial dengan ilmu-ilmu sosial. Seperti yang diungkapkan Welton dan Mallan ( 1981 ), Duffie dan Sagl ( 1966 ) dalam Maksum ( 1997:12 ) menyatakan bahwa IPS bukan hanya kurang popular tetapi juga sering "disalahtafsirkan" dan "dikacaukan" dengan ilmu-ilmu sosial. Secara konseptual maupun oprasional IPS erat hubungannya dengan studi sosial ( Kurikulum, 1994:149 ). IPS diberi pengertian sebagai pelajaran yang mempelajari kehidupan sosial yang didasarkan pada bahan kajian geografi, ekonomi, sosiologi, antropologi, tata negara dan sejarah, yang disajikan secara sistematis dan psikologis. IPS merupakan perpaduan antara konsep-konsep ilmu sosial dengan konsep-konsep Pendidikan yang dikaji secara sistemaits, psikologis dan fungsional sesuai dengan tingkat perkembangan anak didik (Somantri, 1996:2). Perpaduan antara ilmu-ilmu sosial 
dan Pendidikan dalam sajian IPS disebut dengan istilah sinthetyc disiplin. Srini (1996/1997 : 22), mengemukakan bahwa proses dan perkembangan belajar siswa sekolah dasar memiliki kecenderungankecenderungan sebagai berikut :

"Beranjak dari hal-hal yang konkret, memandang segala sesuatu yang dipelajari sebagai suatu keutuhan, terpadu dan melalui proses manipulatif. Oleh karena itu pembelajara di sekolah dasar harus direncankan, dilaksanakan dan pada gilirannya dinilai berdasarkan kecenderungan-kecenderungan di atas".

Dengan demikian bahwa proses pembelajaran IPS di sekolah dasar bukan hanya untuk memahami pengetahuan tentang fakta-fakta pengertian dan konsepkonsep IPS saja yang cenderung bersifat hapalan, melainkan juga mengembangkan ketrampilan dan sikap yang diperlukan untuk mencapai pengetahuan itu. Jelaslah bahwa dari siswa dituntut untuk menggunakan metode ilmiah dan bersikap ilmiah untuk memecahkan masalahmasalah yang dihadapi dengan lebih menyadari kebesara dan kekuasaan Allah SWT. Menurut Piaget (Hilda dan Margaretha, 2002:98) :

"Perkembangan interaksi dengan objek-objek di lingkungan siswa mempunai pengaruh yang lebih kuat terhadap berfikir siswa daripada yang ditimbulakan oleh pengetahuan yang disampaikan melalui cerita yang bersifat verbal. Jadi membawa siswa ke lingkungan asli dari objek yang diamati dapat menunjang perkembangan berikutnya".

Dari uraian di atas dapat disimpulkan bahwa penggunaan lingkugan sebagai sumber belajar banyak manfaatnya baik dari motivasi belajar, aktivitas belajar siswa, kekayaan informasi yang diperoleh siswa, interaksi sosial siswa, pengenalan lingkungan, serta sikap mencintai terhadap lingkungan. Lingkungan dapat digunakan untuk pengembanagn ketrampilan proses dan dapat pula mengembangkan sikap ilmiah. Sehingga lingkungan betul-betul menjadi sumber belajar bagi siswa dalam proses Pendidikan dan pembelajaran IPS di sekolah dasar.

Model pembelajaran ini merupakan model pembelajaran yang dikemukakan oleh Sharran ( 1992 ). Model ini menggambarkan tentang siswa yang melakukan penyelesaian permasalahan dan dilakukan secara berkelompok.

Langkah - langkah model pemelajaran group investigatio antara lain : (a) Siswa dibagi dalam beberapa kelompok heterogen (b) Gurumemberikan penjelasan maksud pembelejaran dan tugas kelompok (c) Setiap kelompok mendapat tugas yang berbeda dengan kelompok lain (d) Masing - masing kelompok membahas tugas secara kooperatif dan bersifat penemuan (e) Salah satu anggota kelompok melaporkan hasilpembahasan kelompok (f) Guru menyimpulak dan mengevaluasi

Metode diskusi harus diatur sehingga jawaban terhadap masalah yang memerlukan diskusi itu tidak diketahui oleh para siswa. Dalam hal-hal tertentu memang tidak mudah untuk mengenali apakah suatu diskusi dikatakan berhasil atau tidak, maka indikatornya adalah adanya partisipasi aktif dari seluruh siswa terlibat langsung dalam mengemukakan pendapatnya masing-masing yang akhirnya untuk mendapatkan berbagai pemikiran yang berbeda-beda untk dapat digunakan dalam menarik kesimpulan. Tujuan pembenahan teknik diskusi agar siswa dapat : (a) Mengembangkan pengetahuannya untuk mengatasi masalah (b) Menyampaikan pendapatnya dengan bahasa yang baik dan benar (c) Menghargai pendapat orang lain (d) Berpikir kreatif dan kritis. Dalam diskusi siswa dilatih untuk (a) Merumuskan masalah (b) Menetapkan tema pembicaraan (c) Menyampaikan pendapat dengan bahasa yang baik dan benar (d) Menghargai pendapat orang lain 
Keunggulan metode diskusi adalah dapat mengarahkan pikiran dan pusat perhatian siswa pada suatu jalur tertentu. Dengan metode diskusi dapat melakukan kegiatan Bahasa Indonesia yang ekonomis, disamping dapat menghemat waktu, guru dapat mengatur persiapan yang memadai dan penyajian diskusi dapat berjalan dengan lancar.

Teknik kelompok sebagai salah satu strategi belajar mengajar. Ialah suatu cara mengajar, dimana siswa di dalam kelas dipandang sebagai suatu kelompok. Setiap kelompok terdiri dari 5 (lima) atau 7 (tujuh) siswa, mereka bekerja bersama dalam memecahkan masalah, atau melaksanakan tugas tertentu, dan berusaha mencapai tujuan pengajaran yang ditentukan pula oleh guru. Adapun pengelompokkan itu biasanya didasarkan pada: (1) Adanya alat pelajaran yang tidak mencukupi jumlahnya. (2) Kemampuan belajar siswa (3) Minat Khusus (4) Memperbesar partisipasi siswa. (5) Pembagian tugas atau pekerjaan. (6) Kerja sama yang efektif.

\section{METODE}

Subjek dalam penelitain ini, adalah siswa kelas IV SDN Siwalanrejo Kecamatan Sukodadi Kabupaten Lamongan Tahun Pelajaran 2017/2018 sebanyak 17 siswa. Waktu Penelitian dilaksanakan selama 4 bulan dengan rincian :

- Bulan Pebruari 2018 : merancang dan menyusun usulan.

- $\quad$ Bulan Maret - April 2018 : pelaksanaan tindakan

hasil penelitian

Bulan Mei 2018 : merevisi

Bulan Juni 2018 : menulis / menyususn laporan PTK

Lokasi penelitian di SDN Siwalan Kecamatan Sukodadi Kabupaten Lamongan. Secara kualitas, subjek penelitian berjumlah 17 siswa. Peneliti memilih subjek penelitian tersebut dikarenakan beberapa hal antara lain : (a) Pemanfaatan lingkungan sumber belajar telah diajarkan di kelas IV (b) Dalam observasi awal yang dilakukan peneliti ditemukan temuan-temuan yang menunjukkan bahwa subjek penelitian yang dalam hal ini siswa kelas IV SDN Siwalanrejo Kecamatan Sukodadi Kabupaten Lamongan kurang berminat menggunakan lingkungan sekitar sebagai sumber belajar karena memang sangat jarang di gunakan dalam PBM. Jenis penelitian ini berbentuk penelitian tindakan kelas (classroom action research) yaitu suatu bentuk kajian melalui self reflection. Sesuai dengan jenis data yang diperoleh, penelitian ini menggunakan desain penelitian tindakan kelas. Berdasarkan siklus-siklus rencana pelaksanaan tondakan digambarkan seperti berikut:

\section{Siklus I}

\section{Perencanaan}

Langkah - langkah atau tindakan yang akan dilaksanakan secara rinci sehingga benar-benar dapat dijadikan pegangan dalam melaksanakan tindakan meskipun kemungkinan perubahan yang bersifat penyesuaian tetap harus diberi tempat. (Kasbolah,1998/1999:72). Pada tahap penerapan ini, peneliti menyusun langkah-langkah sebagai berikut:

a. Mengadakan koordinasi dengan guruguru SDN Siwalanrejo Kecamatan Sukodadi Kabupaten Lamongan tentang masalah yang akan dijadikan focus penelitian tentang penggunaan metode diskusi dan kerja kelompok.

b. Menentukan metode yang akan digunakan dalam pembelajaran

c. Menyusun persiapan pembelajaran dengan penggunaan metode diskusi dan kerja kelompok.

d. Menyiapkan alat bantu yang diperlukan.

e. Menentukan instrumen yang akan digunakan dalam penelitian.

Pelaksanaan Tindakan 
Pada tahap peneliti terutama guru, melakukan tindakan yang berupa intervensi terhadap pelaksaan kegiatan atau program yang menjadi tugas seharihari. Dalam konteks penelitian tindakan kelas, istilah tindakan dipahami sebagai aktivitas yang dirancang dengan sistematis untuk menghasilkan adanya peningkatan atau perbaikan dalam proses pembelajaran dan praktek Pendidikan dalam kondisi kelas tertentu. ( Sumarno dalam Kasbulah,1998/1999:87-88).

\section{Observasi}

Menurut Kasbolah (1998/1999:91) bahwa observasi adalah semua kegiatan yang ditunjukkan untuk mengenali, merekam, yang dicapai (perubahan yang terjadi) baik yang ditimbulkan terencana, maupun akibat sampingannya. Sedangkan sasaran dalam observasi yaitu sebagai berikut : (1) Seberapa jauh pelaksanaan tindakan kelas sesuai dengan rencana tindakan yang ditetapkan sebelumnya ; (2) Seberapa banyak pelaksanaan tindakan telah menunjukkan tanda-tanda akan tercapainya tujuan tindakan ; (3) Apakah terjadi dampak tambahan atau lanjutan yang positif meskipun tidak direncanakan ; (4) Apakah terjadi dampak sampingan yang negative sehingga merugikan atau cenderung mengganggu kegiatan lainnya. (Sumarno dalam Kasbolah, 1998/1999:9394). Kegiatan observasi dilakukan oleh peneliti secara langsung dalam proses pembelajaran dengan menggunakan pedoman observasi (instrument-instrumen penelitian) yang telah disiapkan sebelumnya, sesuai dengan acuan pendapat para ahli di atas. Hal ini untuk melihat hasil atau dampak dari tindakan yang dilaksanakan serta untuk mengetahui sejauh mana pengaruli tindakan yang dikaitkan dengan hasil belajar siswa. Hasil observasi merupakan bahan pertimbangan untuk melaksanakan refleksi dan revisi rencana dan tindakan yang telah dilakukan untuk menyusun rencana dan tindakan selanjutnya yang diharapkan lebih baik dari tindakan yang telah dilaksanakan.

\section{Refleksi}

Pada dasarnya refleksi merupakan kegiatan analisis sintesis, interpretasi, dan eksplanasi (penjelasan) terhadap semua informasi yang diperoleh dari pelaksanaan tindakan. Setiap informasi yang didapatkan hendaknya dikaji dan dipahami bersama (penelilti dan praktisi). Refleksi seyogyanya dilakukan (1) pada saat memikirkan tindakan yang akan dilakukan ; (2) ketika tindakan sedang dilakukan ; dan (3) setelah tinsdakan dilakukan. Ketiga konteks kegiatan refleksi ini oleh Killion dan Todnen dalam Kasbolah (1998/1999:100) dinamakan reflection for action, reflection in action, reflection on action. Dinamakan refleksi karena focus telaahnya tidak terbatas pada diri guru sendiri, tetapi mencakup seluruh konteks pembelajaran yang dilakukannya, bahkan termasuk siswa . Berdasarkan pendapat di atas, dapat diidentifikasi bahwa dalam kegiatan refleksi ini tercakup kegiatan analisis, interpretasi, dan evaluasi atas inform,asi yang diperoleh dari kegiatan observasi. Dalam kegiatan ini peneliti juga mengadakan diskusi dan konsultasi dengan rekan-rekan guru di SDN Siwalanrejo Kecamatan Sukodadi Kabupaten Lamongan Tahun Pelajaran 2017/2018 untuk memberikan masukan dalam memecahkan masalah yang dihadapi. Dari hasil temuan dalam pelaksanaan kegiatan pembelajaran dapat ditindaklanjuti dengan refleksi, karena melalui proses refleksi dapat diambil kesimpulan untuk disajikan acuan perubahan kearah perbaikan dan peningkatan kualitas pembelajaran yang diterapkan pada pelaksanaan siklus berikutnya.

\section{Siklus II}

Pada tahap ini peneliti menunggu hasil refleksi pada siklus I. Jika siklus I dinyatakan tidak berhasil, maka merekomendasikan ke siklus berikutnya. Maka siklus II di laksanakan sesuai dengan langkah-langkah pada siklus I, tetapi ada perbedaan pada jenis pengamatan obyek. 


\section{Instrumen Penelitian}

Instrumen yang digunakan dalam penelitian ini adalah : (1) Rencana Pelaksanaan Pembelajaran ( RPP ) (2) Inter View (Wawancara) (3) Lembar Kerja Siswa ( L K S ) (4) Tes Hasil Belajar Analisis Data

Analisis data merupakan usaha (proses), menulis, memilih, membuang dan menggolongkan data untuk menjawab dua masalah pokok, yaitu (1) tema apa yang dapat ditemukan pada data-data ini dan (2) seberapa jauh data-data ini dapat menyongkong tema tersebut (Sukidin, dkk.2002:111).

Data diolah dan disajikan secara kualitatif deskriptif. Prosedur pengolahan data dalam penelitian ini dapat dijelaskan sebagai berikut:

1. Pengumpulan Data

Mengumpulkan data adalah mengamati variable yang akan diteliti dengan metode interview, tes, observasi, kuesioner, dan sebagainya (Arikunto, 2002:207). Dalam hal ini peneliti mengumpulkan data yang telah diperoleh berdasarkan instrument peneliti yaitu hasil observasi, wawancara (interview) dan hasil test yang diberikan. Data-data tersebut diberi identitas berdasarkan jenisnya sehingga memudahkan interpretasi data.

2. Validasi Data

Teknik validasi data yang digunakan dalam penelitian adalah : (a) Triangulasi Data dan b. Member Check

\section{SIKLUS I}

Pelaksanaan tindakan dan observasi pembelajaran tindakan pertama dilaksanakan penulis tanggal 6 dan 20 Maret 2018 beralokasi di ruang kelas IV SDN Siwalanrejo . Kegiatan proses pembelajaran dimulai dengan pembacaan doa bersama. Selesai berdoa, siswa dipimpin ketua murid berdiri dan mengucapkan salam bersama-sama,. Setelah dibalas salam oleh guru, siswa duduk kembali. Setelah melaksanakan apresiasi, guru membagikan LKS kepada setiap kelompok, Kepada siswa, guru mengisyaratkan agar bekerjasama dalam menjawab pertanyaan yang ada di dalam LKS dalam setiap kelompok. Kegiatan laporan dalam diskusi kelas ternyata memacu siswa berfikir kritis dan berpendapat secara aktif. Setelah semua kelompok selesai memberikan laporannya, guru membahas setiap permasalahan dengan memberikan penjelasan dengan jawaban yang sebenarnya.

Dari hasil pengamatan terhadap pelaksanaan tindakan pertama, dalam proses pembelajaran dengan "penggunaan model pembelajaran group investigation dengan metode diskusi dan kerja kelompok " masih memiliki kelemahan dalam penerapannya, diantaranya dalam pengolahan waktu masih belum efektif dengan adanya kelebihan penggunaan waktu dari alokasi yang ditentukan. Aktivasi siswa selama mengadakan pengamatan belum optimal dan seluruh siswa belum berperan aktif dalam menentukan pengamatan. Aktivasi kelompok sebagian besar didominasi oleh ketua kelompok dan beberapa anggota saja. Sebagian siswa masih belum memiliki rasa tanggung jawab serta kerja sama dalam kelompoknya. Dari segi hasil, ada peningkatan namun masih belum mencapai jumlah yang maksimal. Dan jumlah siswa sebanyak 17 orang baru hanya 8 orang ( $47 \%$ ) saja yang dinyatakan lulus. Dari hasil kelompok, belum seluruh kelompok dinyatakan lulus dari target yang telah ditentukan. Hal ini membutuhkan bimbingan ke arah peningkatan yang lebih baik. Berdasarkan refleksi dan analisis terhadap jalannya proses pembelajaran pada tindakan pertama ini maka perlu mengadakan perbaikan bagi pembelajaran berikutnya, yaitu : (a) Dalam proses pembelajaran, hendaknya guru mengacu pada rencana pembelajara, pembagian waktu harus efektif, sehingga Kegiatan pembelajaran tidak menyita waktu mata pelajaran 
berikutnya dan dalam memberikan petunjuk pelaksanaan Kegiatan kepada siswa harus jelas, mengarahkan kembali pada aturan tata tertib belajar. (b) Proses pembelajaran perlu lebih meningkatkan aktifitas seluruh siswa, tidak hanya didominasi oleh ketua kelompok atau beberapa orang anggota saja, tapi harus semua terlibat aktif. (c) Kegiatan pelaporan dalam diskusi kelas, guru harus memberikan motivasi untuk menumbuhkan keberanian siswa. Siswa dipacu untuk dapat menggunakan pengetahuan dan pengalamannya dalam memecahkan masalah tanpa ketergantungan pada pendapat orang lain. (d) Dalam proses pembelajaran, guru harus menyisipkan penanaman budi pekerti agar siswa selain memiliki akhlak yang baik dengan mencintai lingkungan sekitar dan mensyukuri serta mengakui kebesaran Tuhan pencipta alam.

\section{SIKLUS II}

Mencermati rancangan pembelajaran yang berbatuk Rencana Pelaksanaan Penbelajaran serta analisis rancangan pembelajaran, maka ditetapkan permasalahan pada tindakan kedua yaitu :

1. Pelaksanaan Tindakan dan Observasi pembelajaran Tindakan Kedua

Pelaksanaan tindakan dan observasi pembalajaran tindakan kedua dilaksanakan pada tanggal 10 dan 24 April 2018. beralokasi di ruang kelas IV SDN Siwalanrejo . Kegiatan awal yang dilakukan oleh guru adalah melakukan pretes (tes awal), tujuannya adalah untuk mendapatkan informasi kemampuan awal siswa tentang materi sumber daya alam yang tidak dapat diperbarui, sehingga guru dapat menyesuaikan kadalaman materi pelajaran yang akan diajarkan.

Setelah pre tes guru mengajak siswa ke luar kelas untuk mengadakan pengamatan di lingkungan sekolah tentang sumber daya alam yang tidak $\begin{array}{lrr}\text { dapat diperbarui. } & \text { Sebelum } \\ \text { melaksanakan } & \text { kegiatan } & \text { siswa }\end{array}$ berkumpul di halaman sekolah dengan posisi melingkar. Guru memberikan petunjuk tentang cara melakukan pengamatan dengan bahasa yang mudah dimengerti oleh siswa. Hal ini untuk menghindari kesalahankesalahan yang terjadi seperti pada tindakan pertama.

Sebagai pedoman dalam melakukan pengamatan, guru memberikan LKS kepada setiap kelompok. aktivitas siswa tiap kelompok, selama kegiatan berlangsung terlihat dari kerja sama dalam mengemukakan pendapat dari penemuannya. Bahkan kadang-kadang terjadi perdebatan antara anggota kelompoknya. Untuk meluruskan pendapat siswa, guru mengarahkan jawaban yang benar dengan tidak mematahkan semangat siswa.

Sebagai kegiatan akhir, guru pembimbing siswa membuat kesimpulan lalu guru memberikan penekanan dan intisari materi pelajaran yang telah disanpaikan. Untuk mengetahui keberhasilan proses pembelajaran, ditempuh dengan melakukan evaluasi.

2. Refleksi, Analisis dan Revisi Pelaksanaan Tindakan Kedua

Berdasarkan hasil observasi terhadap kegiatan pembelajaran kedua pelaksanaan tindakan kedua telah menunjukkan perubahan sebagai perbaikan tindakan pertama.

Pembelajaran dengan menggunakan metode diskusi dan kerja kelompok dapat meningkatkan pola pembelajaran yang diselenggarakan guru menjadi lebih bermakn. Kebermaknaan ini ditandai dengan adanya partisiasi aktif siswa yang tinggi serta keterlibatan yang maksimal. Hanya saja kemampuan dan ketrampilan guru dalam menyelenggarakan diskusi mesih perlu dikembangkan da dibiasakan. Hal ketrampila guru dalam 
menyelenggarkan diskusi serta memandu siswa dalam melaksanakan Kegiatan diskusi masih perludikembangkan dan dibiasakan. Hal ini terjadi karena guru kurang terbiasa melaksanakan cara ini dalam kegiatan pembelajaran.

Disepakati bahwa aktivitas siswa selama diskusi merupakan bahan evaluasi, demikian juga aktivatas siswa selama kegiatan observasi. Sebagai upaya untuk meningkatkan kualitas pembelajaran tindakan berikutnya guru perlu memperbaiki berbagai kekurangan dari proses pembelajaran yang telah dilaksanakan guna peningkatan mutu pembelajaran pada tindakan berikutnya.

\section{KESIMPULAN}

Setelah melakuakan Kegiatan penelitian pada proses pembelajaran IPS dengan menggunakan metode diskusi dan kerja kelompok di Kelas IV SDN Siwalanrejo Kecamatan Sukodadi Kabupaten Lamongan Tahun Pelajaran 2017/2018, yang dilaksanakan sebanyak dua kali tindakan dapat disimpulkan sebagai berikut: (1) Penggunaan model pembelajaran group investigation melalui metode diskusi dan kerja kelompok dalam pembelajaran Pendidikan IPS dapat meningkatkan kualitas pembelajaran. (2) Dengan menggunakan model pembelajaran group investigation melalui metode diskusi dan kerja kelompok dapat meningkatkan perolehan hasil belajar siswa kelas IV di SDN Siwalanrejo Kecamatan Sukodadi. (3) Penggunakan model pembelajaran group investigation melalui metode diskusi dan kerja kelompok dapat meningkatkan persepsi siswa terhadap pelajaran IPS. (4) Penggunakan model pembelajaran group investigation melalui metode diskusi dan kerja kelompok dapat mengatasi kendala dalam pelaksanaan proses pembelajaran IPS.

\section{DAFTAR PUSTAKA}

Arikunto, Suharsimi. 2002. Prosedur Penelitian Suatu Pendekatan Praktek. Jakarta: Rineksa Cipta.

Prof. Suhardjono, 2011, Penelitian Tindakan Kelas Dan Sekolah, Malang Cakrawala Indonesia.

Departemen Pendidikan Nasional (2007), PAKEM, Jakarta.

Departemen Pendidikan Nasional ( 2006 ), Kurikulum 2006. Stadar Kompetensi dan Kompetensi Dasar. Jakarta

Mastur, dkk ( 2007 ). Ilmu Pengetahuan Sosial Kelas IV. Semarang : Aneka Ilmu

Rosyada, Dede ( 2004 ). Paradigma Pendidikan Demokratis. Jakarta : Prenada Media

Suradisastra, Djojo, Syamsudin Helius, dkk. Pendidikan IPS. Surabaya, Universitas Negeri Surabaya

Wardani I.G.A.K : Wihardit $\mathrm{K}$ dana Nasoetion, N ( 2003 ). Penelitian Tindakan Kelas. Jakarta : Universitas Terbuka 